\title{
Corporate Charitable Giving
}

\author{
Victor Brudney $\dagger$ \\ Allen Ferrell $\dagger \dagger$
}

Of the multitude of questions that beset analysis of the functions of, and justifications for, philanthropy, one subset is generated by the phenomenon of charitable giving by business corporations. Do (or should) such corporations have the power to make philanthropic gifts? If so, what are the functions of such giving and what, if any, should be its limits? In light of the functions and limits on such giving, who in the structure of the corporation (management? stockholders collectively? stockholders individually? others?) should make the decisions as to the amounts to be given and as to the identity of the donees?

There has been episodic discussion over whether corporations do, or should, have the power, by management decision or majority (or even unanimous) shareholder vote, to make philanthropic gifts. If a business expenditure is one from which the corporation cannot possibly derive any benefit of any kind, common law doctrine suggests that the enterprise lacks the power to do so, at least as against dissenting stockholders' claims if not also third persons' claims. The theory appears to be (regardless of whether it is cast in terms of ultra vires) that the legal function of the corporation and its management is to preserve and enhance the value of the assets for its stockholders. This can only be done legitimately if some net benefit to the corporation and its stockholders follows, or is reasonably expected to follow, from its use or expenditure of such assets. Legislation, by expressly empowering corporations to make charitable gifts, ${ }^{2}$ has undercut the doctrinal obstacle to the power to make such gifts.

$\dagger$ Weld Professor of Law, Emeritus, Harvard Law School.

it Assistant Professor of Law, Harvard Law School.

1 Symposium: Corporate Social Responsibility: Paradigm or Paradox?,84 Cornell L Rev 1133 (1999); Corporate Philanthropy Symposium, 28 Stetson L Rev 1 (1998); Nancy J.Knauer, The Paradox of Corporate Giving:Tax Expenditures, the Nature of the Corporation, and the Social Construction of Charity, 44 DePaul L Rev 1 (1994); Faith Stevelman Kahn,Pandora's Box: Managerial Discretion and the Problem of Corporate Philanthropy, 44 UCLA L Rev 581 (1994); David L. Engel, An Approach to Corporate Social Responsibility, 32 Stan L Rev 1 (1979); Henry G. Manne, The Limits and Rationale of Corporate Altruism: An Individualistic Model, 59 Va L Rev 708 (1973); Phillip I. Blumberg, Corporate Responsibility and the Social Crisis, 50 BU L Rev 157 (1970).

2 See, for example, 8 Del Code Ann \& 122(9) (2001) (granting corporations the power to "[m]ake donations for the public welfare or for charitable, scientific or educational purposes, and in time of war or other national emergency in aid thereof"); Model Business Corporation Act §3.02(13) (1998) (granting corporations the power "to make donations for the public welfare, or for charitable, scientific, or educational purposes"); id at $\$ 3.02(15)$ (granting corporations the power "to make payments or donations, or do any other act, not inconsistent with law, that furthers the business and 
Reasonable arguments can be offered to support such power in corporations.

However, acknowledgment of this corporate power shifts the inquiry to the question of authority - who in the corporate structure is (or should be) authorized to cause a charitable expenditure from which no benefit of any kind is (or is expected to be) received by the corporation or its stockholders? This paper focuses on whether this authority should be vested in stockholders individually or in corporate management. ${ }^{3}$

It is important to note at the outset that this paper focuses on only certain kinds of currently denominated corporate charitable donations. Many corporate charitable donations to nonprofit enterprises or charities are indistinguishable from ordinary business expenditures made to realize imminent, visible corporate operating gains. ${ }^{4}$ Other corporate do-

affairs of the corporation"). The provisions thus "empowering" the corporation eliminate any argument about ultra vires, but they do not state who in the corporate structure should decide on designees. For variations among state statutes, see Faith Stevelman Kahn, Legislatures, Courts and the SEC: Reflections on Silence and Power in Corporate and Securities Law, 41 NY L Sch L Rev 1107, 1110-15 (1997).

3 In theory other stakeholders (for example, employees, creditors, customers, and suppliers) could also be considered.

4 See Sophia A. Muirhead, Corporate Contributions: The View from 50 Years 8-9, Research Report No 1249-99-RR (Conference Board 1999). In the late nineteenth and early twentieth centuries, labor-related considerations dictated such corporate charitable giving (for example, railroads giving to the YMCA to house their workers). See F. Emerson Andrews, Philanthropic Giving 235-36 (Russell Sage Foundation 1950). See also authorities cited in Marion R. Fremont-Smith, Philanthropy and the Business Corporation 10-11 (Russell Sage Foundation 1972). More recently, contributions are significant components of programs of marketing or advertising the corporation's products and services and attracting employee loyalty by associating the corporate identity and its products or services with a particular cause (like child care and welfare, family life, environment, or health causes) or a widely publicized nonprofit event (such as college or amateur sporting events or the Olympies). See, for example, Knauer, 44 DePaul L Rev at 60-71 (cited in note 1) (analyzing the marketing functions of charitable giving); Edwin McDowell, The Parade of Corporate Sponsors: Marketers Line $U_{P}$ to Link Their Names to Events, NY Times C1 (July 16,1999) (detailing corporate sponsorship of festivals, fairs and annual events). By publicly and visibly connecting to those activities, the corporation seeks to attract the approval of consumers of its goods, products, or services and the loyalty of its employees who are affected by their interest in the causes or events thus subsidized. Correlatively, fundraisers for such enterprises seek to sell their aura to the "donating" business corporation. See, for example, Timothy S.Mescon and Donn J.Tilson, Corporate Philanthropy:A Strategic Approach to the Bottom Line, 29 Cal Mgt 49,51-58 (1987) (discussing the "new-style philanthropy" that emphasizes tangible returns for corporate gifts);1999 Cone/Roper Cause Related Trends Report:The Evolution of Cause Branding 18, 19-22 (Cone). Such charitable expenditures differ from the corporation's more conventional mechanisms for affecting its sales and marketing, in part because they less explicitly tout the quality or benefit of its products and in part because they entail hiring an outside nonprofit enterprise instead of an outside for-profit advertising enterprise to sell the corporation's products or services. But each may plausibly be said to require decisionmaking by management-both by reason of their integration with other operations of the business and by the claimed identifiable significance of their contributions to the bottom line. Similarly, corporate contributions include "loans" of corporate executives or employees to serve in the charitable organization. Muirhead, Corporate Contributions at 9. These contributions should "mesh with the company's markets or employees."Id at 7. But commentators suggest that there is little reliable evidence to connect such giving with the bottom line. For a general discussion, see Knauer, 44 DePaul L Rev at 53-56 (cited in note 1); Kahn, 44 UCLA L Rev at 662-74 (cited in note 1); Kenneth B. Davis, Jr., Discretion of Corporate Manage- 
nations can be characterized as "goodwill" gifts that seek to improve the public image of the corporation (rather than simply the loyalty and efforts of its employees or the immediate attractiveness to consumers of its products or services) in a way that arguably will produce future intangible benefits from a favorable public image of the firm. The corporate welfare that is said to be promoted by such giving (including giving to expressive and research organizations) is public approval of the corporation's role as a "good citizen."That public appreciation entails a vision of the corporation as a player in a society that does not welcome regulation or taxation of business. ${ }^{6}$ The corporate benefit from that public attitude cannot be measured in accounting terms,' but it apparently counts to le-

ment to Do Good at the Expense of Shareholder Gain-A Survey of, and Commentary on, the U.S. Corporate Law, 13 Can-US L J 65-67 (1988) (asserting that some charitable activities are closely linked with corporate activities).

5 See A.P. Smith Manufacturing Co v Barlow, 98 A2d 581, 583-86 (NJ 1953) (discussing indirect corporate benefits flowing from charitable donations). Such corporate giving is, and appears to be, remote from the company's visible business needs. Essentially unrestricted gifts to universities, nonprofit medical or scientific research, art museums, concert or opera companies, public enterprises like libraries or public television, "think tanks" or many kinds of institutions that render services to the community and carry the aura of motherhood and apple pie, like the Red Cross or the Girl Scouts, create the kind of good will that warms the hearts of the corporation's public relations experts. That those expenditures may also result in a general enhanced receptivity for the enterprises' products or services or loyalty from its employees is a happy additional benefit, but does not appear to be at the core of the drive to donate. Essentially, the "benefit" that these expenditures can be said to offer to the corporation may reflect managerial long-term strategic conceptions, but they need not be arranged by management to mesh with the daily or short-term operations of the enterprise. Nor do they benefit the contributing firm alone. Its competitors often share the benefits. In short, such goodwill expenditures are not functionally integrated with any particular corporation's business operations and are considerably more remote from the bottom line. See Knauer, $44 \mathrm{DePaul} L \mathrm{Rev}$ at 49-60, 71-74 (cited in note 1) (discussing the importance of the proclaimed benefits of corporate charitable giving, despite the lack of empirical evidence linking corporate giving to corporate profits); Michelle Sinclair and Joseph Galaskiewicz, Corporate-Nonprofit Partnerships:Varieties and Covariates, 41 NY L Sch L Rev 1059,1086 (1997) ("Some [charitable] partnerships ... benefit third parties and are difficult to evaluate.").

6 See Jerome L. Himmelstein, Looking Good and Doing Good: Corporate Philanthropy and Corporate Power 25-28 (Indiana 1997) (noting a fear of government intrusion and regulation as a reason for corporate giving); Joseph Galaskiewicz, Corporate Contributions to Charity:Nothing More than a Marketing Strategy, in Richard Magat, ed, Philanthropic Giving: Studies in Varieties and Goals 246,250-52 (Oxford 1989) (discussing contributions as a tax strategy). See also Knauer, $44 \mathrm{DePaul} \mathrm{L}$ Rev at 57-60,57 nn 319-20 (cited in note 1) (analyzing the "halo effect" corporate giving may have on corporations, especially to compensate for corporate transgressions); Stephen Garone, The Link between Corporate Citizenship and Financial Performance at 12, Research Report No 1234-99-RR (Conference Board 1999) (explaining that corporate good citizenship "can help companies smooth the way to regulatory approvals and reduce the penalties and costs of noncompliance with regulations"); Henry Manne, Book Review: Corporate Control and Business Behavior, $44 \mathrm{~J}$ Bus 451, 454 (1971).

7 That "benefit" was urged as the "benefit" to the contributing corporations by the proponents of corporate charity who launched the mid-century campaign for judicial approval.See, for example, A.P. Smith Manufacturing $\mathrm{Co}, 98 \mathrm{~A} 2 \mathrm{~d}$ at $582-83$. But over time, special benefit to corporate profitability has been claimed for such contributions. Consider Davis, 13 Can-US L J at 19-28 (cited in note 4) (discussing both good will and projected profits as reasons for corporate charity). The evidence for such "benefit" (studied in the context of cause-related marketing) consists of reports of fa- 
gitimize the donation and to distinguish it from a gift for which absolutely nothing is received and that would be unauthorized unless approved unanimously by the stockholders. Our discussion of corporate charitable donations will be concerned with this goodwill corporate giving.

The answer to the question of who should have the authority to make such goodwill gifts turns in fair part on the conception of the "benefit" that the corporation must receive from making the gift if it is to be a valid corporate act. Courts have created, and some commentators have offered, a somewhat strained explanation of what constitutes this benefit. All recognize that corporations, as inert constructs, are unable to derive the emotional satisfaction that accrues to the altruistic individual donor from making a philanthropic gift, or to engage the moral values of doing so that individuals may pursue. Hence, even if the corporate function could tolerate expenditures for no conceivable return, the emotional drive that energizes such gifts by individuals is lacking and the moral quality of such behavior must be explained on different grounds than those that explain or support gifts by individuals.

If individual altruism were envisioned, at least in part, as an exchange - the gift by the individual "in exchange" for the "benefit" of feeling virtuous or acting as a moral member of society - an analogy might be fashioned for corporate giving. The corporation that gives funds or other assets to a charity, notwithstanding that it receives nothing in return that can reasonably be traced to identifiable reduced costs or increased revenues or profits, could be said to be making a charitable gift if "in exchange" therefore it gains some intangible benefit, such as public

vorable consumer, investor, and employee attitudes toward companies that contribute to "good causes," like curing or preventing cancer, curbing drug abuse, or aiding public education and childcare. 1999 Cone/Roper Cause-Related Trends Report at 15 (cited in note 4). The Cone/Roper Report places considerable emphasis on the public's response to cause-related marketing and the views of "influential Americans" (described as "socially and politically active opinion leaders," id at 4, whose "lead" Americans follow, id at 8). Garone, The Link between Corporate Citizenship and Financial Performance (cited in note 6), also relies largely on reported favorable attitudes of investors, consumers, and employees as well as on regulatory benefits. See also Center on Philanthropy at Indiana University, Giving USA 200183 (American Association of Fundraising Counsel Trust for Philanthropy 2001). The problematic character of such benefits and recognition of the largely unmet need to justify, in profit-making terms, all expenditures to produce them are discussed in Paul McAvoy and Ira Millstein, Corporate Philanthropy vs. Corporate Purpose, in Corporate Philanthropy: Philosophy, Management, Trends, Background 25 (Council on Foundations 1982).

8 It has been urged that the combination of people, assets, and organization embedded in the corporate form may appropriately be deemed "enabled" and "obliged" to act morally. See Peter A. French, Collective and Corporate Responsibility 31-47 (Columbia 1984) (analyzing the corporation as a moral person); Meir Dan-Cohen, Freedoms of Collective Speech: A Theory of Protected Communications by Organizations, Communities, and the State, 79 Cal L Rev 1229, $1244-48$ (1991). Even if so, the only action the corporation can decide to take must be decided by individual human agents. Although under corporate forms and laws governing public investor-owned corporations in the U.S., those agents are generally corporate management, that allocation of decisionmaking authority is not graven in stone. 
approval of its image as a moral player in society. The "benefit" represented by such approval, although not the "direct benefit" that early common law required, has for some time been held (in corporate law) to justify management authorization of corporate expenditures that produce no other gain to the corporation or its stockholders. As knowledgeable commentators have pointed out, the result is that corporations are empowered, and management is authorized, to make "gifts which, at the time they are made, are altruistic in the sense that they cannot be justified as profit-maximizing actions.",

We assume the proposition by which "the classic problem of corporate philanthropy" is solved: that the intangible benefit a corporation receives from goodwill giving is not regarded as a "return" from the gift in deciding whether the gift is charitable, and therefore deductible as such for federal income tax purposes; but it is regarded as a "return" from the gift in deciding whether the gift generates a "benefit," which corporate law has historically required in order to make the gift a permissible expenditure of corporate assets. But the question remains: given the unusual character of the expenditure and the "return" or "benefit" from it, who in the corporate structure should have the authority to designate the recipients of corporate charitable gift-giving?

Commentators have discussed whether management's decisions to distribute corporate funds as goodwill gifts should be prohibited or be restrained by special rules (perhaps requiring shareholder collective consent) fashioned either by legislatures or by courts. "Few, however, argue for the prohibition of all such gifts. Suggested judicially fashioned restrictions on management selection of designees are in the fiduciary mode ${ }^{12}$

9 See, for example, Corporate Philanthropy Symposium:Transcript of Proceedings-Corporate Charity: Societal Boon or Shareholder Bust?, 28 Stetson L Rev 52, 82-83 (1998) (quoting Professor Melvin Aron Eisenberg's discussion of morality as a conduct norm for corporate giving).

10 R. Franklin Balotti and James J.Hanks, Jr., Giving at the Office: A Reappraisal of Charitable Contributions by Corporations, 54 Bus Law 965, 967 (1999). The ingenious analyses of economists, organization theorists, and legal academics explaining all charitable gifts as motivated by, and contributing to, profit maximization do not detract from this conclusion. For a general discussion, see Rikki Abzug and Natalie J. Webb, Rational and Extra-Rational Motivations for Corporate Giving: Complementing Economic Theory with Organization Science, 41 NY L Sch L Rev 1035 (1997); Corporate Philanthropy Symposium, 28 Stetson L Rev at 1 (cited in note 1). The contribution of such gifts to any reasonable concept of the present value of the enterprise is so uncertain and ephemeral that it can fairly be said to be doubtful that its return equals its cost, much less exceeds it.

11 See Medical Committee for Human Rights v SEC, 432 F2d 659, 681 (DC Cir 1970) (discussing shareholder participation in corporate decisions motivated by morals or philosophy rather than profit maximization), vacd as moot, 404 US 403 (1972); Fremont-Smith, Philanthropy and the Business Corporation at 27-28 (cited in note 4) (relating statistical evidence that shareholders continually vote down restrictions of the type mentioned in the accompanying text). Compare Political Donations by Companies: A Consultative Document, URN 997757 (UK Department of Trade and Industry Mar 1999) (recommending shareholder approval of corporate donations to political parties). See also Balotti and Hanks, 54 Bus Law at 992-96 (cited in note 10) (positing a framework to regulate corporate charitable giving).

12 Compare Balotti and Hanks, 54 Bus Law at 992-96 (cited in note 10) (suggesting that courts 
and are likely to constrain management even more modestly than does the fiduciary concept in restraining more traditional managerial selfserving behavior.

Another possibility - designation by each stockholder of the beneficiaries of such corporate giving -is generated by the practice of at least one publicly held corporation. ${ }^{3}$ In that case, management decides that a certain portion of the firm's charitable gifts is to be distributed as goodwill giving in a particular year and announces to its stockholders that it will distribute that amount to such enterprises as its stockholders choose individually, and to no others. Under a comparable program, each stockholder would be entitled to direct the distribution of a portion of the aggregate amount set aside by the corporation that equals the proportion of the number of shares of common (residual) stock the stockholder owns to the total number of such shares outstanding. Amounts not thus assigned to donees could remain in the corporate till or possibly become part of the pool to be distributed either by management in its discretion or in the proportions determined by those shareholders who do designate donees.

There is little doubt that management, rather than stockholders, should decide how much the corporation donates (for example, have responsibility for setting aside the funds to be given away for goodwill gifts). That is a function that has much in common with the decision whether to declare dividends or to reinvest corporate funds. It entails the problems that centralized management is designed to address. But once that decision is made, it is not essential for corporate well-being that the choices of donees of the corporation's goodwill gifts be made by management or even by shareholder collective action.

It is also reasonably clear that some kinds of corporate contribution programs are so closely integrated with operational efforts to enhance sales of products or services or the loyalty and satisfaction of employees that their operation (including designation of donees) may reasonably be assimilated to the functions of centralized management. But for contributions, particularly cash contributions, ${ }^{14}$ that function solely or predominantly to build a publicly favorable corporate image or encourage a stable society congenial to business interests, , there are, as we shall see, good reasons for shareholder intervention.

are best equipped to develop and implement standards overseeing corporate giving, and advocating a modern rule), with Kahn, 44 UCLA L Rev at 594-609 (cited in note 1) (discussing state legislative efforts regarding the regulation of corporate philanthropy).

13 See Lawrence A. Cunningham, The Essays of Warren Buffett: Lessons for Corporate America, 19 Cardozo L Rev 5, 47-50 (1997) (reproducing a Buffett letter that is regularly part of the corporation's annual report detailing shareholder participation in designating charitable recipients in Berkshire Hathaway, Inc).

14 And possibly for corporate charitable contributions in the form of products, if not in the form of services or use of equipment.

15 For example, contributions to organizations categorized as "Education," "Culture/Arts" 
To be sure, the question of who in the corporate structure should make such choices is of modest import if the monetary amounts that it implicates were the only relevant dimension for assessment. During recent years, corporate charitable giving has aggregated little more than 5 percent of total charitable giving in the United States, which in 1998 amounted to $\$ 174.52$ billion and in 2000 to $\$ 203.45$ billion. ${ }^{16}$ Of those totals, corporations and corporate foundations gave $\$ 8.97$ billion or 5.1 percent in 1998 and $\$ 10.86$ billion or 5.3 percent in $2000 .{ }^{17}$ If giving to religious organizations were excluded (because there is very little such giving by investor-owned corporations), the corporate portion of total charitable giving would have been approximately 9.2 percent in 1998 and 8.4 percent in $2000 .{ }^{18}$ Moreover, goodwill giving involves only a portion of the charitable gifts claimed by corporations.

The amounts involved in such goodwill giving may be modest if measured against total charitable giving, and trivial if measured against corporate expenses or gross or net income. ${ }^{20}$ However, the question

(such as enterprises in the performing arts, museums, and libraries), and expressive or advocacy organizations. For a description of categories of beneficiaries, see Muirhead, Corporate Contributions at 60 (cited in note 4). Contributions to enterprises in the category "Health and Human Services" may also function in this manner, but their role often combines more immediate benefits to the corporation.

16 Center on Philanthropy, Giving USA 2001 at 20 (cited in note 7). The problem does not exist significantly in the case of closely held corporations, which are effectively indistinguishable as donors from their stockholders.

17 Center on Philanthropy, Giving USA 2001 at 20 (cited in note 7); Center on Philanthropy at Indiana University, Giving USA 199920 (American Association of Fundraising Counsel Trust for Philanthropy 1999).

18 Center on Philanthropy, Giving USA 2001 at 20 (cited in note 7). See also Cunningham, 19 Cardozo L Rev at 54 (cited in note 13) (reproducing a Buffett letter stating that "publicly-held companies almost never allow gifts to churches and synagogues"). Significantly, there is no category "Religion" in the description of distributees of corporate charity in the Giving USA series or in the Conference Board reports on corporate charitable giving. Computation of total charitable giving to the category "Religion" could include giving to churches or houses of worship as well as to affiliated organizations that operate under their umbrella. If the latter gifts are included, religion received, on average, for the years 1978-1999,50 percent of all charitable gifts. See Center on Philanthropy, Giving USA 2001 at 87 (cited in note 7). But there was a sharp decline during the last few years to a low of 36.5 percent in 2000 . Id.

19 It is difficult to determine how much, if any, of cause-related giving or other sponsored giving is included in the above figures for corporate charitable giving. For some years such giving is said to have been close in amount to goodwill giving. See Center on Philanthropy, Giving USA 1999 at 69 (cited in note 17). As the Conference Board has pointed out, "Although companies tend to find that noncash contributions are more cost-effective and meet the needs of beneficiaries best, they are often difficult to measure, and are often reported as business expenses instead of contributions. Consequently, contributions budgets do not reflect the totality of giving at many companies." Muirhead, Corporate Contributions at 9 (cited in note 4).

20 See David R. Morgan, Trends in Corporate Charitable Contributions, 41 NY L Sch L Rev 771,786 (1997) ("[Corporate charitable contributions] are basically an insurance policy against unhappy consequences that might result were no charitable contribution made at all."); Marina Dundjerski, Companies Forecast First Significant Increases in Giving in 5 Years, 7 Chron Philanthropy 12, 12 (Sept 21, 1995) (stating that U.S. companies gave less than 1 percent of their pretax income to charity in 1994). Corporate giving, on average, rarely exceeds 1.5 percent of pretax corporate income, 
whether shareholders individually rather than management should be given the authority to designate donees of corporate goodwill donations is of some interest, if not importance. The answer to that question implicates considerations of both corporate and stockholder welfare as well as the public interest in charitable giving.

\section{THE VIRTUES (AND VICES) OF SHAREHOLDER CHOICE}

Placing authority to designate beneficiaries of corporate charitable gifts in stockholders individually rather than in management implicates two kinds of inquiries. One is whether doing so will increase shareholder wealth - possibly by reducing agency costs and the cost of capital. Second, apart from the purely economic question of maximizing shareholder welfare, there are important public policy questions involved in the allocation of decisionmaking power over corporate goodwill gift-giving. The function and effect of such giving are less to advantage the enterprise in the economic market than to give "the corporation" a role in affecting the kinds of social services to be delivered and the moral values to be developed in society. Decisions on these matters by corporate management may well produce different results than decisions by individual shareholders. The choice between decisionmaking by the former and decisionmaking by the latter implicates the considerations that underlie private (nongovernmental) support of charity and not just considerations affecting corporate efficiency. But exposition is aided by examining the latter before the former.

A. Corporate Wealth Maximization Does Not Require Management Selection of Designees of Goodwill Gifts and May Be Better Served by Individual Stockholder Selection of Such Donees

Before discussing the question whether, as a matter of shareholder wealth maximization, it is preferable to allocate the choice of donees of corporate goodwill giving to stockholders individually, it is appropriate to explain why such an allocation will do little, if any, harm to corporate efficiency or profitability.

The special managerial competence that is required for (and the reasons for denying stockholders a role in) corporate decisions that seek to produce identifiable or measurable enhancement of corporate profit is rarely, if ever, necessary to determine the distributees of goodwill gifts.

although the proportion varies from year to year, ranging from less than 1 percent to 2.1 percent between 1970 and 2000 . The most frequent level is 1.1 percent. See Center on Philanthropy, Giving USA 2001 at 33 (cited in note 7). The uneven and changing character of corporate giving and a breakdown into categories of such giving may be obtained in Muirhead, Corporate Contributions at 60 (cited in note 4), and in annual Conference Board reports, Giving USA, and Fremont-Smith, Philanthropy at 48-52 (cited in note 4). 
Rather, there are good reasons to vest the power to make the latter kinds of decisions in stockholders individually, notwithstanding the possible diluting effect of this system on the value of the goodwill claimed for such gifts.

1. A centralized decisionmaking process for goodwill giving is unnecessary for corporate wealth maximization.

Unlike most expenditures made in the conduct of corporate affairs, donations that seek to create goodwill are discrete expenditures. ${ }^{21}$ They are not necessary parts of a functionally integrated program of expenditures in producing or distributing goods or services that is designed to generate a collective return that can only be feasibly and most profitably achieved by centralized decisionmaking. They are not components of the marketing process that must be taken into account as part of the firm's overall program. Nor are they part of a production process that is affected by the selection of particular donees. At the most general level (for example, gifts to nationally esteemed universities or museums or social service enterprises), they are not likely to have the stimulating effects (enhanced employee productivity) claimed to result from gifts to charities rendering local services in places where the firm has employees $^{2}$ or from matching gifts programs. Indeed, even the employee loyalty or incentive effects of those kinds of gifts are not clear. Possibly no loss in employee productivity would follow if direct increases in compensation were made instead of such gifts. If so, the substantial function of such gifts is more to enhance the corporate image as a good citizen than to increase corporate efficiency or foreseeable profits. There is little need for such donations - from either the donor's or the recipient's point of view - to be coordinated by the centralized decisionmaking process of the kind that is required for financing, producing, or selling the corporate products or services that are the source of the firm's profits. In short, the considerations that argue against stockholder participation in corporate operations do not apply to shareholder decisionmaking about goodwill giving, regardless of whether such giving meets the requirement of corporate "benefit" as that term is expansively interpreted.

21 In this respect they contrast sharply with those "charitable" gifts that entail decisions that cannot rationally be made by yielding to preferences of individual stockholders, or indeed feasibly be made apart from decisions about other, normal operating affairs of the enterprise. They contrast also with expenditures that may materially affect operating results, such as expenditure of funds on equipment to filter exhaust from chimneys or on disposal of toxic wastes.

22 The claim that corporations "need" an educated, if not a specially trained, cadre of potential employees rarely requires that the choice of donees for such purposes is a decision that can "only," or even "best," be made by management as a component that is functionally integrated with the firm's operations.

23 See analysis in Abzug and Webb, 41 NY L Sch L Rev at 1045-58 (cited in note 10). 
The most favorable realistic assessment of the value of managerial (rather than shareholder) choice of donees of goodwill giving is that it is part of a larger corporate strategy that will, over time, effect an advantageous public image of the enterprise. This implicates the public attitude toward government regulation or taxation of business, and toward the corporation's failure to comply with those prescriptions. Selection of some tactics rather than others in pursuit of that strategy may be said to call for contributions directed by management rather than for fractured gifts by individual stockholders. If the question were simply one of creating in the public view an image of a philanthropic strand in the corporate tapestry, it is not clear that a publicly announced program of enabling individual shareholder giving of corporate assets would not produce a public view of the firm equally as benign as that produced by management's selection of particular beneficiaries. ${ }^{24}$ It is not irrelevant in assessing the possible benefit to the corporation of management over stockholder choice to note that the favorable public attitudes toward business fostered by such giving often accrue not only to the contributing corporation but also to its competitors and others, and to that extent present more ephemeral benefits and more complex problems of justification for any particular enterprise. ${ }^{25}$

2. Agency and other costs of managerial discretion in corporate charitable giving programs.

If operational considerations do not preclude shareholder direction of such decisionmaking, considerations of "agency costs" suggest special reason to encourage such direction. Managerial discretion in making profit-oriented expenditures is bounded by the ties of the process for producing profits. To be sure, business judgment leaves much elbow room for managerial discretion in such matters. But strictures against self-serving limit managerial personal gain from abuse of discretion. The tie of the expenditure to a profit-making operation sets a boundary, albeit permeable, from which to measure self-serving diversion of any portion of the expenditure. In contrast, goodwill giving of corporate funds (for example, to a museum, "think tank," the opera, or a university) often results in intangible personal benefits to corporate directors or executives, such as membership on the donee's board, awards of honors, or

24 The notion, sometimes urged, that the public "expects" the corporation, as a good citizen, to make charitable contributions, see, for example, A.P. Smith Manufacturing Co v Barlow, 98 A2d 581, 585-86 (NJ 1953); Muirhead, Corporate Contributions at 10 (cited in note 4), may or may not be an accurate statement of what the public "expects." But that putative expectation, which management's fuglemen generate for management, if not for the public, does not require the choice of donees of corporate charity to be made by management rather than by stockholders-except as it is an expectation already created by management strategy.

25 See Manne, 59 Va L Rev at 710 (cited in note 1). 
other forms of acclaim by the donee or one's peers. ${ }^{25}$ Such reciprocity is too ephemeral to be feasibly identified in court as improperly "purchased" for the manager by the corporate gift. ${ }^{27}$ The resulting "benefits" to management may or may not be great, but they hardly correspond to any identifiable corporate benefit from giving to one donee rather than to a myriad of others. Moreover, managerial choice of beneficiary may entail the power to purchase dilution of directorial supervision of managerial conduct. ${ }^{23}$ Those "benefits" come at stockholder expense from funds otherwise distributable to stockholders because they are not essential to corporate operations. The propriety of managerial choices is not likely to be a subject of monitoring by stockholders, ${ }^{29}$ particularly since their choices are not generally publicly identified $d^{30}$ or ever listed as compensation to executives. That the mechanism for making corporate con-

26 See Sinclair and Galaskiewicz, 41 NY L Sch L Rev at 1060 (cited in note 5) (asserting that charitable contributions "are a form of executive perquisite"); Evelyn Brody, Charities in Tax Reform: Threats to Subsidies Overt and Covert, 66 Tenn L Rev 687, 714-15 (1998) (detailing reasons other than tax subsidies that might motivate corporate charity); Knauer, 44 DePaul L Rev at 83-85 (cited in note 1) (discussing evidence of increased corporate charity where managers of peer firms associate with each other in social settings); James R. Boatsman and Sanjay Gupta, Taxes and Corporate Charity: Empirical Evidence from Micro-Level Panel Data, 49 Natl Tax J 193, 199-201 (1996) (analyzing managerial motivations for corporate giving).See also Cunningham, 19 Cardozo L Rev at 52 (cited in note 13) (discussing the incidence of corporations matching gifts made personally by board incumbents to charities of their choice).

27 See Kahn v Sullivan, 594 A2d 48,59-63 (Del 1991) (involving a corporate charitable donation to fund an art museum to house the corporate controller's collection); Jayne W.Barnard, Corporate Philanthropy, Executives ${ }^{2}$ Pet Charities and the Agency Problem, 41 NY L Sch L Rev 1147,116470 (1997) (examining conflicts of interest in the context of executives' pet charities and advocating disclosure as a check on abuses); E.C. Lashbrooke, Jr., Internal Revenue Code Section 170 and the Great Corporate Giveaway, 22 Pac L J 221, 248 (1991) (arguing that charitable giving is bottom-line oriented, so charitable deductions should not be allowed); Kahn,44 UCLA L Rev at 609-25 (cited in note 1) (analyzing the role of managerial self-interest in corporate charity); Kahn, 41 NY L Sch L Rev at 1107 (cited in note 2) (discussing the discretionary authority of managers in corporate giving); Balotti and Hanks, 54 Bus Law at 980-83 (cited in note 10) (criticizing the lack of accountability for managers' charitable giving decisions); Bill Shaw and Frederick R. Post, $A$ Moral Basis for Corporate Philosophy, 12 J Bus Ethics 745, 750 (1993) (arguing that utilitarianism provides a moral basis for corporate social responsibility); Developments in the Law-Nonprofit Corporations, 105 HarvLRev 1578,1612-34 (1992) (arguing for a community values standard to determine tax-exempt status for charities); Boatsman and Gupta, 49 Natl Tax J at 193 (cited in note 26) (arguing that managers' utility, not profits, motivates corporate charitable giving); Knauer, 44 DePaul L Rev at 83-85 (cited in note 1) (arguing that corporate giving can be viewed as social currency); Manne, $59 \mathrm{Va}$ L Rev at 72021 (cited in note 1) (arguing that managerial self-interest may motivate some corporate giving). See also Cunningham, 19 Cardozo L Rev at 47 (cited in note 13).

28 Richard A. Oppel, Jr. and Floyd Norris, In New Filing, Enron Reports Debt Squeeze, NY Times C1 (Nov 20, 2001). Compare Lewis v J.B. Fuqua, 502 A2d 962, 965-67 (1985).

29 See Davis, 13 Can-US LJ at 17-19 (cited in note 4) (discussing the lack of enforceable standards in assessing managerial conduct).

30 A number of companies have gone so far as to attempt to exclude from corporate proxy materials shareholders' proposals for the corporation to disclose information about its charitable giving: for example, IBM (Jan 31, 1994) and AT\&T (Jan 9, 1979).

31 An exception to this is so-called "charitable awards" that constitute a form of executive compensation. See SECRelease No 33-6962 (Oct 21,1992). See also Cunningham, 19 Cardozo LRev at 47-54 (cited in note 13) (Buffett letter); General Electric Corp, Notice of 2002 Annual Meeting and 
tributions has evolved from more or less idiosyncratic choices by CEOs into an organized process with distinct personnel and departments within the corporate structure of many corporations does not significantly alter the incentive problem.

Broader considerations of economic efficiency suggest that managerial decisionmaking may be more costly than permitting individual stockholders to choose donees of corporate goodwill giving. Stockholders do not gain from such corporate gifts by subordinating their individual philanthropic preferences to centralized decisionmaking, except as the more or less remote benefits from such decisionmaking can be said to enhance the corporate image and therefore corporate wealth. Any such ambiguous and uncertain enhancement, however, is bought at the cost of requiring investors to invest jointly in the corporation's profitmaking activity and its philanthropic activity. If investors were able to invest only in the profit-making activity, rational investors would charge less for their capital than if its use were tied to charitable giving to donees they have no voice in selecting, particularly if they oppose the activities of the recipient charity. ${ }^{33}$ So long as "agency" benefits from such "bundling" are enjoyed by management, unbundled investments are not likely to be offered by corporations so as to compete away the bundling by offering unbundling. To be sure, the matter may not be of large practical significance in most investors' choices in view of the relatively small amounts involved. But the aggregate costs are real, and in practice such giving could affect investors who are self-conscious about charitable causes. $^{34}$

The corporate benefit, if any, from management designation of corporate goodwill gifts is uncertain in effect and immeasurable in amount, ${ }^{35}$ and in any event is apt to be modest. Its costs (agency costs and increased cost of capital) are likewise uncertain and difficult to measure.

Proxy Statement 14 (2002); General Electric Corp, Notice of 2001 Annual Meeting and Proxy Statement 15 (2001).

32 A number of commentators have noted the influence corporate management retains over corporate charitable giving. See, for example, Kahn, 44 UCLA L Rev at 591(cited in note 1).

33 It is hard to find many investors who would charge less for the package because they prefer the bundle (profits plus management choice of charitable donees) to the single item.

34 For example, labor unions and church groups.

35 In summarizing the effects of corporate charitable giving over a period of fifty years, the Conference Board has said, " $[E]$ vidence is showing that effective corporate citizenship enhances corporate reputation and increases public trust in a company. In addition, there is evidence that the effect of corporate citizenship on economic performance need not be harmful to shareholder value... and, in specific instances, can even add to it." Muirhead, Corporate Contributions at 9 (cited in note 4). The question of effect on shareholder value is difficult to answer because, as the Conference Board report also pointed out, "the amount all companies have given correlates with corporate profits ... [and] closely parallels both individual companies' economic fortunes and executives' attitudes." Id at 6 . It is hard to tell which way causality runs.

36 See generally Garone, The Link between Corporate Citizenship and Financial Performance (cited in note 6). Compare Boatman and Gupta, 49 Natl Tax J at 194-201 (cited in note 26) (listing 
Placing decisionmaking power in individual stockholders could reduce those costs, but it may diminish the benefits ${ }^{37}$ and incur other costs. ${ }^{38} \mathrm{It}$ is difficult to envision (and to conduct) empirical research that will resolve the uncertainties as to the balance of corporate benefits and costs. This leaves the matter at worst undetermined, and at best modestly in favor of one beneficiary-designating process over the other, ${ }^{39}$ and on balance, we believe, in favor of the shareholder choice alternative.

深米米

Before turning to the larger policy issues, it is worth noting that it is unnecessary, in examining or resolving the question of who should choose donees of corporate charity, to enter or revisit the subject that is compendiously called "corporate social responsibility." That subject is concerned with the extent, if any, to which the assets of the corporation designed to be used in operations seeking to maximize the wealth of its shareholders should be called upon to meet societal problems. This paper does not entail examination of that subject because it is concerned with the uses made only of that portion of the corporation's assets that is not essential to its wealth-maximizing operations. On the contrary, the ex-

contribution factors and possible costs), with Peter Navarro, Why Do Corporations Give to Charity?, $61 \mathrm{~J}$ Bus 65, 80-81 (1988). See also Sinclair and Galaskiewicz, 41 NY L Sch L Rev at 1082 (cited in note 5) (relating agency theory to managerial charitable decisionmaking); Craig Smith, Desperately Seeking Data:Why Research Is Crucial to the New Corporate Philanthropy, in Dwight F. Burlingame and Dennis R. Young, eds, Corporate Philanthropy at the Crossroads 1,2 (Indiana 1996) (stating that CEOs have to justify the costs of charitable contributions).

37 Precluding management from designating beneficiaries of corporate charity and authorizing stockholders to do so will likely dilute the particular image of corporate "good citizenship" that management prefers, and it may frustrate fulfillment of the public's "expectation" of such good citizenship. See also note 24 . However, in the calculation of lost benefit from denying management choice, account must be taken of the offsetting benefit to the corporation of a regime in which the corporation publicly makes the charitable gifts but the designees are selected by stockholders individually from among recipients that society prefers to subsidize. Any such "lost" benefit is difficult to calculate, particularly since individual stockholder choice of donees is likely to relieve the enterprise of the cost of stockholder public disagreement and controversy over corporate goodwill gifts. See, for example, 2001 Annual Report of Berkshire Hathaway, Inc 17 (2001);2001 Proxy Statement of Berkshire Hathaway, Inc 7 (2001).

38 The transaction costs of shareholder choice may be offset in part by reduction of corporate staff who attend to charitable giving.

39 While there are many claims of benefits to the corporation from goodwill giving, there is little hard evidence. There is anecdotal evidence, and a more persuasive rationale, for recognizing agency and bundling costs. The benefits lost from, and the costs of, shareholder as compared to management choice are no more measurable, except perhaps for differences in transactions costs. See Smith, Desperately Seeking Data at 2-3 (cited in note 36) (arguing that corporate philanthropy is a business function that, like all business functions, requires research); Sinclair and Galaskiewicz, 41 NY L Sch L Rev at 1076-84 (cited in note 5) (analyzing various factors that may influence corporate charity) (1997). Compare Boatsman and Gupta, 49 Natl Tax J at 208 (cited in note 26) (disputing the assumption that charitable giving is motivated by business concerns), with Navarro, Why Do Corporations Give, $61 \mathrm{~J}$ Bus at 89-90 (cited in note 36) (arguing that profit maximization is a stronger motivation than managerial discretion for corporate charitable giving); authorities cited in note 4 . 
penditures with which this paper is concerned have a dubious, if nonexistent, function in maximizing the efficiency of corporate operations or of its shareholders' wealth. The social responsibility involved in this paper concerns who in the corporation should designate donees of corporate donations, not whether the corporation has an obligation to make such donations in the first place.

\section{B. Stockholder Selection of Donees Serves the Societal Values of Philanthropy and the Function of Private Decisionmaking on the Objects of Philanthropy Better than Management Selection}

Apart from considerations of corporate efficiency, corporate goodwill giving implicates questions of social policy. That "business" plays a significant role in generating and shaping values in society-by the social services and welfare programs it chooses to support, by the ideologies it articulates and public attitudes it encourages through its support of nonprofit expressive associations - is both a "fact" and a continuing aspiration of business. ${ }^{40}$

It is unnecessary for purposes of this paper to resolve the questions of whether, or to what extent, private charity should substitute for, or merely supplement, government support for the goods or services that charitable enterprises produce. ${ }^{41}$ Some of these goods or services cannot feasibly be offered unless funded by government. ${ }^{42}$ Others can be sustained entirely by private giving, and indeed, it is fairly argued that government should be precluded from offering them. ${ }^{3}$ Many can be offered by enterprises that enjoy the combined support of government and private giving. ${ }^{4}$ It may be assumed that it is permissible, if not also preferable, for private giving to support some activities that might be supported by government as well as some that might not be. It is unnecessary here to resolve the questions of which activities (or how extensively they) should be privately supported. It is enough for present purposes to recognize that private contributions to fund the goods or services pro-

40 J.A.C. Hetherington, Fact and Legal Theory: Shareholders, Managers, and Corporate Social Responsibility, 21 Stan L Rev 248,286-92 (1969) (arguing that traditional legal and business theories have not recognized the role of corporate power in public policy); Muirhead, Corporate Contributions at 35-47 (cited in note 4); Jerome L. Himmelstein, Corporate Philanthropy and Business Power, in Dwight F. Burlingame and Dennis R. Young, eds, Corporate Philanthropy at the Crossroads 144, 147-50 (Indiana 1996) (discussing the intimate tie between corporations and nonprofit organizations).

41 "Private" charity could refer only to voluntary gifts with no government subsidy to the donor or it could refer to private gifts that are government-subsidized, as by tax deductibility to the donor. For present purposes the distinction is irrelevant, although it is worth noting that in the U.S. all private charitable giving is thus subsidized.

42 For example, employment for individuals whom the private sector "cannot" employ; health care for those to whom it cannot be supplied adequately by the private sector.

43 For example, religious activities.

44 For example, universities and museums. 
vided by such charitable activities represent private support for a public purpose. Such donations are essentially "other directed," even though making them gives personal satisfaction or pleasure to the donors. And they often function to fund goods or services that create public benefits but that would otherwise not be offered except possibly by government. ${ }^{45}$

1. The moral claims of "the corporation" to be a donor to charity, and their social import.

The essential justification for corporate philanthropy, if any exists, is grounded in the notion of the corporation as a "member" of society, with attendant moral and social obligations. The claim that "the corporation" owes society something in return for the privileges that society makes available rests either on the premise that each of us "owes" society something for similar reasons, or that the corporation may be viewed as a specially privileged entity that owes something special in return for its privileges. On the former view, it is hard to see why stockholders are not more appropriate selectors than management of how to satisfy that debt, which is paid from their assets that are not essential for corporate profitmaking. On the latter view, significant questions of policy are raised in deciding whether management or stockholders should be the designators of how corporations should pay that debt. That debt to society could be paid by taxes on the corporation's operations or profits, at least if repayment is its function, and therefore selection of distributees is irrelevant. But corporate goodwill giving is not simply the payment of a debt to society. It also entails choosing what kind of "good" society needs or should have. That the "good" may be deemed to be made available by reason of the management-stimulated stream of corporate earnings does not justify giving management, rather than stockholders, the power to determine what kind of social service or moral "good" a portion of that stream should nurture.

Notwithstanding theoretical arguments suggesting the existence of "corporate" capacity for altruism and the legitimacy of "its" participating in making political or social choices, the only process by which "it" can make such choices entails action by human beings. ${ }^{46}$ The "corporation," in and of itself, has no more claim or competence to make charitable donations to welfare or educational or arts institutions or to generate ideological values than it has a "soul to be damned [or a] body to be

45 In this connection, it is interesting to note the claim by "business" that, while it cannot replace all the needeci social services eliminated by government cutbacks, "business" should provide funding for some of the services eliminated. Muirhead, Corporate Contributions at 35 (cited in note 4). See also note 68.

46 See Shaw and Post, $12 \mathrm{~J}$ Bus Ethics at 745 (cited in note 27) (discussing whether a "corporation," like an individual, can act charitably). 
kicked." "Nor does "it" have any capacity to "make" such donations except as they are caused to be made by human actors who, under current allocations of power, are the corporation's managers. Whether conceptually the managers (executives and directors) are "agents" of "the corporation" or of its stockholders when they make such donations is of small relevance for present purposes. ${ }^{48}$ In the former case, the "principal" is incapable of telling the agent what donation to make." In the latter case, the question is whether the "principal" may appropriately claim decisionmaking power for itself. It is not simply a matter of management gaining satisfaction for itself by giving away stockholders' assets. It is the choice of which donees or "goods" will be subsidized by stockholders' assets that is at issue.

If the choice of donees is seen as an implementation of the moral principles of the donor, it is hard to see why the choice should be made by management. It has no special moral competence to make such choices, at least with assets that are not "its." Nor is it chosen by stockholders to do so. And it is not the special function of centralized management to make those choices about goodwill gifts with assets to which stockholders have considerably greater claims than does management.

Managers may, and doubtless do, donate their own funds to charitable organizations or enterprises engaged in furthering (or advocating) social and moral values or welfare services that they prefer. But management is not engaging in such altruism when it directs donation of funds that do not belong to it, and from the donation of which it can suffer no cost as a predicate for its moral or emotional satisfaction. Whatever may be the breadth of the concept "altruism," it does not cover giving away someone else's "interest" in property for the benefit of still others whom the "owner" may have no desire to benefit, and indeed may object to benefiting. When the donation is made effectively from stock-

47 Mervyn A. King, Public Policy and the Corporation 1 (Chapman and Hall 1997) (quoting Edward, First Baron Thurlow (1731-1806) on the notion of a corporate conscience); Robert G. Bone, A New Look at Trade Secret Law: Doctrine in Search of Justification, 86 Cal L Rev 241, 285 (1998) ("Corporations ... do not possess attributes of personal autonomy or the capacity for intimate relationships.").

48 It is unnecessary to resolve that question in the context of this paper.

49 The only restraints on management's choice in such matters are either judicial monitoring of open-ended fiduciary constraints or shareholder monitoring of managerial discretion, neither of which is apt to be a significant restraint. See Davis, 13 Can-US L J at 17-19 (cited in note 4) (discussing traditional fiduciary law notions with regard to managerial accountability).

50 If the corporation is viewed as a "nexus of contracts," the question is whether the "contract" between stockholders and "the corporation" or management should be interpreted to vest charitable donation power in stockholders rather than management when its "text" is silent on the matter.

51 This is not less true when the gift is made by an agent appointed for other purposes or by a group organized for other purposes. Individuals could, and no doubt do, yield decisionmaking to others on use of donations they altruistically make (for example, expenditures by the recipient organizations' staffs). But when they invest in profit-seeking corporations, they need not necessarily or rationally intend to yield discretion as to the moral choice of recipients of charitable donations to man- 
holders' funds, the moral decisionmaking capacity to give, and to select the donee, whether for altruistic or for ideological choices, is more appropriately found in those who can claim forgoing some sort of ownership interest in the property being given to support the donees' activities. If such expenditures by management are justifiable as gifts to support the donors' moral principles, at the very least they require stockholder acquiescence.

As investment incentives and corporate charitable giving are currently structured in our society, stockholder investment in corporations in pursuit of profit hardly constitutes acquiescence in empowerment of management to choose the recipients of corporate goodwill giving. ${ }^{\text {s2 }}$ The implicit (or explicit) consent of investors to centralized management is to directing the enhancement of corporate wealth. It is not given (and need not be given) to effect management's distribution to others of surplus for which the corporation has little or no wealth-increasing use.

In sum, insofar as the selection of charitable recipients should be a response to a felt private preference or moral decision to donate one's property, the stockholders as human beings living in the society are more legitimate determiners of that response than is "the corporation" and "its" stream of earnings or its managers.

No less important is society's interest in its citizens developing and enjoying the virtuous feeling of philanthropic giving to others in society. Philanthropic behavior connects donors to other citizens and encourages their concern with the well-being of others. The corporation lacks the emotional or psychological capacity for that concern. To the extent that such concern among its citizens is a social desideratum, shareholder choice of donees of corporate charitable giving better meets that aspiration than does managerial choice - both because of the larger number of givers thus encouraged to share that concern and because of the larger spread of objects of such concern.

agement or fellow stockholders.

52 The difficulties that attend obtaining actual consent from dispersed stockholders when it is expressly requested in order to approve managerial self-dealing are nothing compared to those attending the claim that the act of investing for profit constitutes actual consent to managerial selection of particular goodwill gifts. Apart from all the problems of rational apathy and free riding that affect any expression of shareholder consent, such consent requires adequate disclosure by management, a factor that is absent in managerial selection of donees of goodwill giving. See Kahn, 44 UCLA L Rev at 661-62 (cited in note 1) (asserting that actual shareholder consent depends on adequate information, which is lacking because of insufficient charitable contribution disclosure); Kahn, 41 NY L Sch L Rev at 1132-44 (cited in note 2) (addressing the problems of silence and disclosure in the federal securities regulations). Given that goodwill gifts are often a trivial portion of total corporate expenditures, it is difficult to claim that such giving is an expression of a shareholder's particular moral or ideological preferences or consent to the use by managers of corporate funds for support of any moral or ideological preferences held by the managers. 
2. The societal claims for dispersion of donors (and donees) of corporate charity.

Apart from deferring to the donors' altruism or moral preferences as a premise for requiring individual stockholders rather than management to choose donees of corporate charitable gifts, the role of charity in the society argues against vesting such power in management rather than stockholders. The use of the assets thus given is a use that serves a public good more than a corporate good. ${ }^{33}$ The donor is making the choice of a particular public good to serve. If the government provided that good, there is some basis for believing that the choice would be made by persons whom the public chooses to make such choices and who are responsive to that public. When a public good is to be furnished by private choice, the notion of the public function performed by supplying the good suggests that while individual selectors may be private, overall the selectors of the good should reflect a broader, rather than a narrower, cross-section of the public. ${ }^{34}$ To effectuate that policy, society appropriately may seek to restrict the corporation's ability to give away shareholders' property by allocating decisionmaking power to one set rather than another set of participants in the corporation. Without resort to the undesirable (and generally intolerable) limits that would be effected by proscribing or prescribing particular charitable gifts or kinds of gifts, the state's corporate rules may, and inevitably will, encourage or discourage such donations by a broader or narrower array of donors to a broader or narrower array of potential donees.

The moral or ideological premises that dictate or limit government's power collectively to allocate or distribute benefits to society and its members do not limit private charitable giving. ${ }^{\text {s5 }}$ Private funders of charities respond to innovative, experimental, and varied motives that do not and possibly should not underpin government funding. Fracturing the corporate donations into streams that stockholders individually prefer will support a broader and more varied array of social services, moral values, and ideologies than management is likely to support. It will correspond more accurately with individual stockholder preferences, ${ }^{\text {s6 }}$ limited as they may be. One of the principal premises that is said to underlie so-

53 See Himmelstein, Corporate Philanthropy and Business Power at 147-50 (cited in note 40) (discussing the corporate interest in supporting charity as an effort to stem the growth of government).

54 This is not to deny that particular individual donors should be free to seek altruistically to benefit particular recipients more than society would.

55 For example, support for religious causes or expression; support for "radical" or unpopular social groups.

56 This is certainly true with respect to satisfying preferences in making donations, for example, to religious institutions, the arts, education, or ideological organizations. It is also likely to be true in the matter of funding social services, medical care, or comparable purposes. 
ciety's interest in charitable giving by its members contemplates the support of a variety of recipients serving a variety of ends that are selected by a range of individuals - a thousand points of light." Pluralism in support of social services, like pluralism in expression of social or moral views, argues strongly for preference for shareholder over managerial designation of corporate goodwill giving. The socially and experientially dispersed shareholders (although far from representative) are more likely to respond to the different preferences and needs for social services in the society than is corporate management. Corporate management is not only a narrower segment of possible charitable donors than dispersed stockholders, but also may well hold views of the public good that will, more than stockholders' views, scant the interests of some portions of the public that, in the absence of government support, it is a legitimate function of private charity to serve.

\section{Implementing Shareholder Choice}

One mechanism for implementing shareholder choice is a statute mandating it for all public investor-owned corporations. Another, preferable, mechanism is a revision of the Internal Revenue Code to permit corporate donations or expenditures to be deducted by those corporations as "charitable" only if the donees are designated as such by stockholders individually. ${ }^{\text {sy }}$ If an expenditure is made in normal profit seeking operations, shareholder involvement is not appropriate and the expenditure should be deductible by the corporation, ${ }^{60}$ but not as a charitable contribution.

57 See Frank Prochaska, Capitalism with a Human Face, Times Literary Supp 14, 14 (Feb 9, 2001) (chronicling a movement to revive philanthropy in Great Britain); Mark A. Hall and John D. Colombo, The Donative Theory of the Charitable Tax Exemption, 52 Ohio St L J 1379,1384-85 (1991) (proposing that the variety of options to a donor helps reveal which charities are of special worth).

58 Corporate contributions to local charities through intermediate distributing organizations seem to have been funneled largely through United Way enterprises in cities across the nation, at least as suggested by Conference Board annual studies. See, for example, Andris Tillman, Contributions in 199726 (Conference Board 1999). See also John A. Yankey, Corporate Support of Nonprofit Organizations, in Dwight F. Burlingame and Dennis R. Young, Corporate Philanthropy at the Crossroads 7,18-20 (Indiana 1996) (discussing the United Way and corporate charity). The United Way is not known to favor as recipients of its allocating function newly formed innovative enterprises or those that focus on unconventional causes. Those groups are often served by community distributing organizations other than the United Way.

59 Compare 26 USC $\$ 170$ (c) (providing for a charitable deduction for corporate donations but not requiring shareholder involvement).

60 Corporate expenses incurred by management can be deducted if they constitute a business expense. 26 USC $\$ 162$. In order to constitute a business expense, the expenditure must be made with a "reasonable expectation of financial return commensurate with the amount of the transfer." 26 CFR \$ 1.170A-1(c)(5) (2002). Charitable or other contributions designated by stockholders are not likely to be considered "business expenses." Whether a deduction is allowed under 26 USC $\$ 162$ or 26 USC $\$ 170$ might not be a matter of indifference if the contribution is regarded as a capital expenditure. The deductibility under 26 USC $\$ 162$ of a capital expenditure would typically be deferred. 
If a program of stockholder-designated goodwill giving is desirable, there is reason to embody it in federal legislation rather than to let it vary from state to state. The problem, at least for publicly held corporations, is national, from the points of view both of the donors and the donees. ${ }^{6}$ There is thus little question of Congress's power to allocate to stockholders of public investor-owned corporations the authority to choose donees of corporate charity under the Commerce Clause ${ }^{62}$ and no question under its taxing power. ${ }^{63}$ If Congress thus has the power to act, none of the restraints on its power under the Contracts, Due Process, or Equal Protection Clauses can seriously be urged to preclude legislation favoring shareholder choice. It is not constitutionally ordained that each kind of corporate expenditure be made only by management or only by stockholders or by any particular combination of them. Government selection of some areas of corporate activity, like charitable expenditures for shareholder decisionmaking and others for management decisionmaking, raises no serious constitutional questions in view of the reasonableness of the classification of activities and the connection of the classification itself with reasonable allocation of decisionmaking power. Nor is there any serious question under the First Amendment. Shareholder choice is not designed to, nor does it, suppress or curtail speech. It simply increases the number and variety of possible voices.

See Linda Sugin, Theories of the Corporation and the Tax Treatment of Corporate Philanthropy, 41 NY L Sch L Rev 835, $845 \mathrm{n} 53$ (1997). Providing that an expenditure is charitable only if it is designated by shareholders individually would relieve the IRS and managers of the problems of "correct" characterization of the expenditures.

61 Corporate goodwill giving is not limited to charities that function in the states in which the corporation is incorporated. Much corporate charitable giving affects donees in the areas in which the corporation operates, and to that extent may be said to be local. But for large corporations with multistate operations, many states (least of all probably the state of incorporation) are involved. In any event, goodwill giving has a broader public purchase. Moreover, the stockholders whose claims are affected are not localized to the donees. Both the stockholders and the beneficiaries affected are dispersed over the entire nation and the amounts involved, at least when aggregated, are not trivial. It is hard to see why donor corporations incorporated in Delaware or New York, but whose operations and donees (and beneficiaries) are elsewhere, should (or must) be subject only to that local law in the internal allocation of corporate power to designate donees.

62 Neither United States v Lopez, 514 US 549, 562 (1995) (holding that the Gun-Free School Zones Act exceeded congressional authority under the Commerce Clause), nor United States $v$ Morrison, 529 US 598, 613 (2000) (holding that the Violence Against Women Act exceeded congressional authority under the Commerce Clause), nor their adumbrations preclude Congress from regulating the allocation of power within the large business corporation to engage in goodwill or other "charitable" giving.

63 The power of Congress to grant deductions for charitable giving is broad enough to support predicating the deduction on a prescription addressed to securing wide dispersion or variation in donors - as by allocating the corporate authority to choose recipients between management and stockholders. Compare South Dakota v Dole, 483 US 203, 210 (1987) (holding that Congress's spending power may be used indirectly to influence states' drinking-age policies), with, for example, United States $v$ Kahriger, 345 US 22, 31 (1953) (holding that the indirect effects of Congress's taxing power do not make a wagering tax unconstitutional). See also Marchetti $v$ United States, 390 US 39, 44 (1958) (stating that Congress has the power to tax illegal activities). 


\section{SOME CONSEQUENCES OF SHAREHOLDER CHOICE}

If in theory stockholder choice is to be preferred over management designation, there remain significant empirical questions concerning the consequences of implementing shareholder choice.

\section{A. Alteration of the Aggregate Amount of Charitable Giving}

The net cost to society in lost charitable dollars (if this is viewed as a loss) of allocating choice of corporate goodwill giving to stockholders is ideally nil. But in practice it may be more than modest if fracturing decisionmaking power will diminish the aggregate amounts that individuals will give or that corporations will set aside for such goodwill giving, or preclude the benefits of long-term strategies that are funded by systematic giving of large sums by corporate donors to particular donees. However, it is not clear that, in the aggregate, lesser amounts will be given from "corporate funds" if corporate gifts are individually designated, or how significant any possible diminution in such support will be.

It is probable that if individual stockholders were given the funds by the corporation, they would not make as large an aggregate contribution to charitable enterprises as would corporate management. The probability arises because if stockholders have the funds in their possession, the endowment effect and free-rider considerations may limit the aggregate amounts of their gifts to less than management (which is not giving away its own money) would have given on behalf of the corporation itself. There could, therefore, be some difference in the aggregate amount of corporate charitable giving.

But the phenomenon is mitigated if each shareholder's failure to designate a recipient for his or her pro rata share of the pool results in that share being retained by the corporation or in its common pool for such gifts. In such a framework, the psychological impulse to refrain from giving what is in one's pocket is diminished.A stockholder who thus has nothing to gain from refraining from making the gift, and indeed has something to lose in the sense that the monies go back into a common pool possibly to be distributed by other stockholders, is more likely to make the gift than if the funds were in the stockholder's pocket alone.

Present income tax structure suggests that if instead of the corporation making the gift and receiving a deduction in computing taxable income, it distributed the funds as dividends and the individual recipients made their own charitable gifts, there might be a loss in the amount of funds available for charity because of the absence of the deduction at the corporate level and the tax on the dividend to the stockholder. But if the

64 Berkshire Hathaway's experience suggests little diminution, although Berkshire Hathaway is hardly an ordinary corporation. See Cunningham, 19 Cardozo L Rev at 50 (cited in note 13). 
stockholder's choice is limited to directing the making of the gift or letting the funds remain in the corporate till, the transaction may not be regarded as a dividend taxable to the stockholder. Any doubt on the matter can be resolved by appropriate legislation, which need not alter the present amount of tax revenue and burden effects.

Management set-asides for corporate goodwill giving by each shareholder, rather than payment of the funds directly to shareholders for each to make (or not make) a gift, might satisfy certain claimed conceptions of the corporation's "good citizen" obligations. Thus "pressuring" the stockholders to give, rather than to keep the funds in the corporation or let others designate donees, can serve the function of assuring that some portion of the profits it generates will "go back" to society. It deprives the shareholders of the freedom to refrain from any charitable giving with those funds. But that leaves them no worse off than under the regime of managerial discretion to choose donees. To be sure, individual donors of portions of the corporate pool may reduce the amount they would otherwise give to charity from their own funds. But it is problematic whether in the matter of altruism such rational calculation will result in significant reduction in aggregate individual giving. ${ }^{\text {.5 }}$

Individualizing corporate contributions may incur other costs, but their magnitude is difficult to measure. Thus, corporate giving under management auspices may make possible the continuous relationship of a single donor of large amounts to long-term programs of a charitable institution. This relationship facilitates planning of costly programs that are to be executed over a long period and monitoring their performance by the donor. The value of such continuity may be lost if corporate giving is fractured into donations designated by individual stockholders. It is possible that similar arrangements - and the values thus generated-may result from systematic designation of donations by individual holders of a corporation's stock or by their foundations, particularly if they act together on projects that they prefer. But it is not unlikely that there will be some loss of philanthropic support for charitable projects financed by corporate donations. However, that loss is likely to be offset by donations from many individual designators to other charitable recipients. Whether there will be a net economic or social gain or loss from thus individualizing is hard to predict.

65 Consider Amos Tversky and Daniel Kahneman, The Framing Decisions and the Psychology of Choice, 211 Science 453 (1981) (discussing the "dependence of preferences on the formulation of decision problems"); Richard H. Thaler, The Winner's Curse: Paradoxes and Anomalies of Economic Life 107-22 (1992) (discussing the framing of mental accounts and the resulting nonfungibility of different forms of saving).

66 The question is made particularly difficult to answer in light of the stability afforded to many long-term welfare services by the crucial role of government in funding (both absolutely and in proportion to other funding) organizations providing such services. A more substantial problem that shifting power to stockholders to select charitable donees may cause relates to the burgeoning 
More directly relevant to the possible reduction in the amounts received by charities from goodwill giving is the likelihood that mandating deference to individual stockholder choice will cause management to decline to authorize any or much goodwill charitable giving because it cannot choose the donees. Management may believe that the corporation will lose, both in terms of its reputation and by loss of the kind of social stability and atmosphere that enhance its wealth-creating capacity, if instead of management's wisdom guiding the giving, the fractured choices of dispersed stockholders determine the identities of the beneficiaries. ${ }^{67}$

There is also the question whether, even if there were little impact on corporate well-being of fracturing this particular kind of charitable giving, management would simply decline to set aside funds for such efforts. It might so decline simply because it would lose the satisfaction (and the benefits) it now gets for the gifts it causes the corporation to make to particular donees. On the premises of corporate law, such reasons for declining to give might well not be legitimate. But it would be hard to ferret out those reasons as the basis for management's declination so as to nullify the declination by imposing costs on management for that illegitimacy. Management reluctance to set aside corporate funds for goodwill giving may thus cause a much larger reduction in the candlepower of a thousand points of light. Such reduction may be significantly lessened, if not eliminated, by authorizing management to designate possible donees for individual shareholder giving, but leaving each shareholder free to choose from such designees or to select others.

To ascertain the appropriate level of philanthropy, or even only of corporate charitable giving, in the society entails incalculable variables, and any conclusion reached would be ambiguous, if not disputable. If such a level were ascertained, and shareholder choice could be shown to be likely to produce less than enough total philanthropic giving than

movement of government-business partnership in funding and operating "charitable" enterprises, such as training young people or retraining others for work skills. Whether the partnership takes the shape of a special government corporation or a separate charitable entity, and whether the services it renders are only training in skills or knowledge related to work or include other "goods," the notion of such government-business cooperation rests on the assumption of management decisions about the levels and kinds of corporate participation. For a general discussion, see Nancy J. Knauer, Reinventing Government: The Promise of Institutional Choice and Government Created Charitable Organizations, 41 NY L Sch L Rev 945 (1997); Community Leaders Trumpet the Rise of Social Enterprise, Harv Univ Gazette (Feb 24,2000), available online at <http://www.news.harvard.edu/gazette/ 2000/02.24/social.html (visited Mar 24, 2002) (discussing the rise in cooperation between private business and nonprofits to effect social change). Possibly stockholder selection of donees of corporate assets would hamper such programs.

67 Cause-related marketing gifts and similar expenditures that are part of normal corporate revenue-increasing, or cost-decreasing, activities may be diminished if the corporation is not allowed a deduction under 26 USC $\$ 162$, and if management believes that this sort of giving will not be costeffective if done by shareholders. But this depends upon the gifts being, and the IRS finding them to be, more (or less) operationally functional rather than charitable. Compare note 60. 
would managerial choice, acceptable measures - possibly by way of tax treatment-could be adopted to create incentives for larger corporate or individual giving.

\section{B. Alteration of Distributees of Charitable Giving}

Corporate management is constrained in its choice of recipients. It is stimulated to choose recipients of the kind that government is under popular pressure to provide, if only because charitable giving thus lessens the pressure for government funding and attendant regulatory and tax consequences that management believes onerous for business. ${ }^{63}$ Structurally, corporate giving, no matter how varied the constituencies that management or staff might personally prefer as recipients, ${ }^{69}$ is limited by the constraints of appearing to serve the corporate interest or at least not to injure it. Corporate gifts to controversial charities are not popular with management, even though some managements are not daunted by attracting unnecessary controversy. ${ }^{70}$ And quite apart from limitations on "giving" caused by the desire to avoid recipients that offer controversial social services, management-directed distributions are likely to go to charities that render services that support values that management considers useful to a "stable" climate for business." Moreover, the culture in which management and management-giving evolves imposes its own limitations on management's conception of "worthy" recipients. "Criticism of the range of causes and organizations funded by corporate donations has been levied by both those on the left and those on the right.

68 See Himmelstein, Looking Good and Doing Good at 25-31 (cited in note 6) (discussing the rise in the culture of corporate philanthropy); Knauer, 41 NY L Sch L Rev at 959 (cited in note 66) (discussing tax incentives for corporate giving); Garone, The Link between Corporate Citizenship and Financial Performance (cited in note 6); McAvoy and Millstein, Corporate Philanthropy vs. Corporate Purpose at 25-26 (cited in note 7) (discussing the need for corporations to fill voids created by government cutbacks). See also note 45 .

69 See Hildy J. Simmons, Symposium: Corporate Philanthropy: Law, Culture, Education and Politics: Luncheon Address, 41 NY L Sch L Rev 1013, 1013-21 (1997); Himmelstein, Looking Good and Doing Good at 38-55 (cited in note 6) (discussing the views of employees of corporate charitable giving departments).

70 See Richard Gibson, Boycott Drive against Pioneer Hi-Bred Shows Perils of Corporate Philanthropy, Wall St J B1 (June 10, 1992) (describing the controversy over Pioneer's support of Planned Parenthood); Himmelstein, Looking Good and Doing Good at 115-20 (cited in note 6) (describing the lack of response corporations give to criticisms by the Capital Research Center of their charitable giving). See 2001 Annual Report of Berkshire Hathaway (cited in 37); 2001 Proxy Statement of Berkshire Hathaway (cited in 37).

71 See Himmelstein, Looking Good and Doing Good at 120-24 (cited in note 6) (discussing disagreements over the proper role business has in society).

72 See id at 14-15,35-37 (discussing the corporate charitable giving phenomenon as a collective business activity); Joseph Galaskiewicz, Professional Networks and the Institutionalization of a Single Mind Set, 50 Am Soc Rev 639, 655-56 (1985) (evaluating the influence of job status, professional networks, and professional proximity upon corporate giving officers' choices to support particular nonprofits). 
At best, the center and breadth of the range of services that management is likely to support through corporate charitable giving are apt to be close to the center and breadth of the range of governmentsupported services, and the focus is more likely to be on services (for needy and not needy) that support, rather than question, prevailing social values. In the aggregate, individual stockholders who are not constrained by such considerations are more likely to distribute donations to services that implicate more extreme social values-those that prevailing mores may find too liberal or too conservative.

Casual examination of readily available sources ${ }^{73}$ suggests difficulties in relying on reported past performance as the basis for predicting future behavior, if only because the classifications of distributees and of the distribution of total giving among them are ambiguous. ${ }^{74}$ The only relatively clear prediction is that if individuals acting as shareholders were to allocate corporate gifts in the same proportions as they have done in the past few years as individuals, a substantial portion of corporate gifts would be directed to recipients in the category "Religion" and a corresponding portion would be diverted from other recipients. ${ }^{75}$

More extensive research than we have conducted is necessary before acceptable estimates can be made of the distributive effects of shareholder choice of distributees other than "Religion." The limited data available permits only speculation about the direction of change among other distributees. If aggregate corporate gifts are not diminished by allocating power to stockholders, possibly the diversion will diminish slightly the proportion of distributed funds to recipients in the combined categories "Culture and Arts" and "Education."By the same token, there is apt to be some increase in the proportion received by enterprises in the category "Health and Human Services,", but perhaps allocated differently among those organizations.

73 For example, the Conference Board reports and Giving USA.

74 The Conference Board's classifications are set forth in one of its research reports. See Muirhead, Corporate Contributions at 60 (cited in note 4). Because the Board's surveys may include only limited nonrandom selections of corporations, its results may not adequately reflect the larger picture. See Center on Philanthropy, Giving USA 2001 at 78 (cited in note 7).

75 During 1978-99, total giving to "Religion" averaged 50 percent of total giving, with gifts declining in 1999 to 44 percent and in 2000 to 36.5 percent. Center on Philanthropy, Giving USA 2001 at 21 (cited in note 7). Corporate charitable donations generally have not gone to "Religion." See also note 18.

76 Cunningham, 19 Cardozo L Rev at 53-54 (cited in note 13) (detailing the distribution of individual Berkshire Hathaway stockholder charitable contributions). Comparison of the proportionate charitable contributions over time of corporations with those of all of society suggests that recipient in the category Health and Human Services will gain slightly and those in the categories Education and Culture/Arts will lose slightly if individual shareholders designate corporate donees. See Center on Philanthropy, Corporate Giving USA at 21,78 (cited in note 7); Center on Philanthropy, Corporate Giving USA 1999 at 21, 68 (cited in note 17). Compare Tillman, Contributions in $199723-$ 25 (cited in note 58 ). 
Corporate goodwill gifts by management are made not only to organizations rendering services but also to expressive associations. In general, that form of giving supports the explicit communications offered by nonprofit enterprises engaged in expressing ideological views that management is likely to favor."

Decisions about social values and how society should be organized to achieve them affect more than the prosperity of the enterprise in which the shareholders have a common interest for which they may appropriately delegate decisionmaking to management. Neither the concept of government regulation (or freedom therefrom) nor the social climate for business is divinely ordained or a natural phenomenon. The former is, albeit imperfectly, the product of political choices that, in democratic theory, are made (if generally indirectly) in response to popular vote on how the society should be organized, its "goods" produced and distributed, and its "goals" effected. The latter is affected in fair part by inputs in the communications offered to the members of the society by those having access to communications facilities.

No doubt stockholders, like managers, value private property and appreciate a climate friendly to business. But a climate congenial to business does not necessarily serve other "goods" that human beings, including stockholders, hold dear, and may entail some "bads" that they oppose. In the tensions, not to mention conflicts, between those values and friendliness to "business" or over the propriety of government taxation or regulation, different people have different preferences. Many may prefer a climate that, in deference to other values, supports some government regulation that a management selected to maximize profits would - and maybe should-oppose. Others believe that managementdirected contributions go to enterprises expressing views that are not sufficiently friendly to business-indeed are antithetical to a free society. ${ }^{n}$

Overall, if individual shareholder selection replaces managerial designation of donees of corporate goodwill gifts, it is probable that no fewer funds will go from the shareholders' pool to relatively established charitable enterprises that render conventional services to the deserving poor. But charities offering innovative, and indeed unpopular, kinds of social services to the undeserving poor are likely to receive, in the aggregate, more funds from individual shareholders than from corporate man-

77 See, for example, David M. Ricci, The Transformation of American Politics: The New Washington and the Rise of Think Tanks 149-81 (Yale 1993) (describing the anatomy of the modern think tank); Himmelstein, Corporate Philanthropy and Business Power at 150 (cited in note 40) ("[C]orporate philanthropy appears ... to promote the general interest of business."); Oliver A. Houck, With Charity for All, 93 Yale L J 1415, 1455-57 (1984).

78 See, for example, William E. Simon, $A$ Time for Truth 231-33 (Reader's Digest 1978) (criticizing business donations to organizations that do not promote capitalism). See also Memorandum from Lewis F. Powell, Jr. to Eugene B. Sydnor, Jr. (Aug 23, 1971) (on file with authors). 
agement. In the same vein, expressive associations with more strident ideological voices are likely to be gainers from individual shareholder designation of beneficiaries. More funds will likely go to support more conservative views than more liberal ones. At the same time, organizations voicing critical, or even radical, social and political views are also likely to receive more funds from individual shareholder designation than from management selection of corporate donees.

\section{PROBLEMS OF ADMINISTRATION}

Even if stockholder choice is desirable and lawful, there are important practical questions that go to the administrative feasibility and transaction costs of such a regime. One problem arises over how to define the class or classes of stock whose holders are to be given individual choice and in what amounts or proportions. How should preferred stock, convertible or other hybrids, and debt securities be treated? One possible (and preferable) solution is to require designation only by holders of claims to residual value (common stock).

For corporations with millions of holders of common stock, there are the standard problems associated with accounting for the wishes of holders of small lots and the resulting transactions costs. Both may be significantly reduced by making stockholder choice available through proxy material, which would have the incidental benefit of encouraging stockholder voting. To be sure, it is more complicated to proportionalize and effectuate a designated contribution by the holder of a small lot than to aggregate his or her votes; and the variety of possible designees suggests that aggregation of designated contributions is not likely to function as simply as aggregation of votes. Considerations of feasibility and cost-saving may, or may not, justify restricting the power to designate contributions to gifts of not less than a certain amount and letting the unused part of the charitable pool (as not all shareholders will be able to meet the threshold) go as management designates or pro rata as the used part is directed by other stockholders.

Of import also are the problems associated with designation by institutional investors (mutual funds, banks, insurance companies, pension funds). The need for a workable solution of the problem for institutional investors is significant in view of the magnitude of their holdings. Obligations to pass-through to individuals the power to designate donees could be imposed, although not without cost. For those organizations for which such obligations are necessary, such as close corporations, exclusions could be crafted. It is also possible that institutional holders might be disqualified from designating donees of portfolio companies' charitable giving unless the institutions offered an acceptable mechanism for giving 
choice to their individual stockholders or participants. In the absence of such mechanisms, the portions of the portfolio companies' charitable pools that therefore cannot be passed through institutional holders would be added to the those companies' pools for choice of designees by their individual shareholders.

The problems surrounding administration are difficult and indeed crucial. In the end, they may make shareholder choice of corporate goodwill donations unfeasible. But the cost of considering the wisdom of such proposals is modest, and not without benefit. Partial solutions may be feasible. The ingenuity of the corporate bar and its academic colleagues should not be underestimated. 